Original Research Article

\title{
Investigation of the estrogenic activity of Pueraria candollei variety mirifica extract on rats
}

\author{
Dao Thi Vui ${ }^{1}$, Nguyen Thu Hang ${ }^{1}$, Nguyen Quoc Huy ${ }^{2}$, Bui Thanh Tung ${ }^{3} *$
}

\begin{abstract}
${ }^{1}$ Department of Pharmacology,
Hanoi University of Pharmacy,

Vietnam

${ }^{2}$ Administration of Science

Technology and Training,

Ministry of Health, Vietnam

${ }^{3}$ Department of Pharmacology

and Clinical medicine, School of

Medicine and Pharmacy,

Vietnam National University Ha Noi, Vietnam
\end{abstract}

Received: 30 May 2019

Revised: 30 June 2019

Accepted: 06 July 2019

*Correspondence to:

Dr. Bui Thanh Tung,

Email: tungasia82@gmail.com

Copyright: () the author(s), publisher and licensee Medip Academy. This is an openaccess article distributed under the terms of the Creative Commons Attribution NonCommercial License, which permits unrestricted noncommercial use, distribution, and reproduction in any medium, provided the original work is properly cited.

\begin{abstract}
Background: Pueraria candollei variety mirifica (PM) has been widely used as ingredient in many rejuvenating products. In this study, we aimed to assess the estrogenic activity of PM extract grown in Vietnam.
\end{abstract}

Methods: Estrogenic activity of PM extract was estimated on immature female rats by using uterotrophic method to measure the weight of the reproductive organs. Estrogenic activity of PM extract also was investigated in mature female ovariectomized rats by evaluating the vaginal cells growth, reproductive organs weight, serum estradiol concentration.

Results: Our results showed that PM extract at doses of $100 \mathrm{mg} / \mathrm{kg}, 200 \mathrm{mg} / \mathrm{kg}$ had increased the reproductive organs weight in immature rats and female ovariectomized rats. In addition, PM extract had increased the serum estradiol concentration and the vaginal cells growth by increasing the percentage of keratinocytes in female ovariectomized rats.

Conclusions: Our results showed that PM extract has strong estrogenic activity in rats.

Keywords: Estrogenic activity, Pueraria mirifica, Uterotropic assay, Vaginal cytology assay, Ovariectomized rats

\section{INTRODUCTION}

Phytoestrogen is a plant estrogen proven effective, less unwanted effects than estrogen in complementary therapies for women with estrogen deficiency. Therefore, the finding for phytoestrogen-rich medicinal plants is a new direction for scientists. Pueraria candollei variety mirifica (Shaw and Suvat) Niyomdham (PM) is widely distributed in the highlands of northern Thailand, Myanmar and Vietnam which has been identified in a high-phytoestrogen component. ${ }^{1}$ Some phytochemicals compounds have been identified in PM extract such as miroestrol, deoxymiroestrol, puerarin, daidzin, genistin, daidzein, genistein and isoflavonoid. ${ }^{2,3}$ Miroestrol was the first phytoestrogen isolated from PM, which has the strong estrogenic potency. ${ }^{1}$ In traditional medicine, PM has been used for a long time with the purpose of improving tonic, beauty for women. Pharmacological studies have shown that PM has anti-osteoporotic effects, anti-collagenase, anti-elastase and antioxidant and also improving estrogenic activity. ${ }^{4-7}$ This study was carried out to evaluating the improving estrogenic activity of the 
PM extract on immature female rats and female ovariectomized rats.

\section{METHODS}

\section{Plant material}

Roots of PM planted in Bac Giang province, Vietnam. The sample was identified as Pueraria candollei var. mirifica (Shaw and Suvat) Niyomdham, Legume (Fabaceae). A voucher specimen has been deposited in the Department of Botanicals-Hanoi Pharmacy University, the code number of HNIP/18159/16.

Dried roots of PM were pulverized and were extracted. Water was added to boil for one hour. This step was repeated three times and combined water extract for all steps. The mixture was then filtered and dried at $60^{\circ} \mathrm{C}$ until it became concentrated extract.

\section{Animals}

White rats, 21-22 days old, healthy, recently weaned female wistar strain (immature), weight 60-80 g, and healthy adult wistar strain, 8 weeks old, weight 140-160 g, were provided by the Military Medical University. Animals were maintained accordingly to a protocol approved by the Hanoi Pharmacy University, Hanoi, Vietnam and following the international rules for animal research. Animals were received water ad libitum as vehicle and standard diet administration.

\section{Effect of PM extract on immature female rats}

After adaptation for five days, immature female rats were randomly divided into four groups, $n=9$ for each group.

- Group 1 (normal group): were given orally distilled water of $1 \mathrm{ml} / 100 \mathrm{~g}$ body weight (b.w.).

- Group 2 (control group): were injected with subcutaneous of estradiol at a dose of $10 \mu \mathrm{g} / \mathrm{kg} \mathrm{b}$.w.

- Group 3: were given orally PM extract at a dose of $100 \mathrm{mg} / \mathrm{kg}$ b.w.

- Group 4: were given orally PM extract at a dose of $200 \mathrm{mg} / \mathrm{kg}$ b.w.

The rats were treated during continuous for 3 days. On the $4^{\text {th }}$ day, sacrificed rats were decapitated under light anesthesia, the reproductive organs were removed (uterines, ovaries, vaginal), weight, then dry at $70^{\circ} \mathrm{C}$ to constant weight and measure weight.

Wetted weight of reproductive organs was calculated as following:

The wetted weight of reproductive organs

$=\frac{\text { The weight of reproductive organs just removed }(\mathrm{mg})}{\text { The weight of the rat }(\mathrm{g})} \times 100$
Dried weight of reproductive organs was calculated as following:

$$
\begin{aligned}
& \text { The dried weight of reproductive organs } \\
& =\frac{\text { The weight of reproductive organs after drying }(\mathrm{mg})}{\text { The weight of the rat }(\mathrm{g})} \times 100
\end{aligned}
$$

Percentage of the increased weight of reproductive organs of treated group as compared to normal group was calculated as following:

$$
\begin{aligned}
& \% \text { Increased } \\
& \text { The weight of reproductive organs of treated group }- \\
& =\frac{\text { The weight of reproductive organs of normal group }}{\text { The weight of reproductive organs of normal group }} \times 100
\end{aligned}
$$

\section{Effect of PM extract on mature female ovariectomized rats}

Female rats were bilaterally ovariectomized by surgical to remove the ovaries, under light ether anesthesia. Healthy ovariectomized rats were maintained after 14 days of removing ovaries. Microscopic examination of vaginal epithelial cells assessing the presence of epithelial cells was conducted to confirm the ovarian removed successfully. Then rats were randomly divided into 4 groups, $\mathrm{n}=9$ for each group:

- Group 1 (control): Ovariectomized rats were given drinking distilled water with a volume of $1 \mathrm{ml} / 100 \mathrm{~g}$ b.w.

- Group 2: Ovariectomized rats were subcutaneously injected estradiol at $2 \mathrm{mg} / \mathrm{kg}$ b.w.

- Group 3: Ovariectomized rats were orally administered at a dose of PM extract $100 \mathrm{mg} / \mathrm{kg} \mathrm{b.w}$.

- Group 4: Ovariectomized rats were orally administered at a dose of PM extract $200 \mathrm{mg} / \mathrm{kg}$ b.w.

Rats were treated continuously during 14 days at 10 am every day. Then vaginal cell growth, increasing weight of reproductive organs, blood estradiol concentration were evaluated. $^{8,9}$

\section{Evaluating the-growth of the vaginal cells}

From the day of treatment vaginal fluids were taken daily, and calculated the percentage of keratinocytes. Vaginal fluids were taken at 9 am every day by pipette $100 \mu \mathrm{l}$ of distilled water into vaginal and then take $25 \mu \mathrm{l}$, stained within 1 minute with $0.5 \%$ methylene blue solution. Counted the number of neutrophils, epithelial cells and keratinocytes. Calculation of the percentage of keratinocytes according to the formula as

$\%$ Keratinocytes $=\frac{\text { Number of keratinocytes }}{\begin{array}{c}\text { Number of neutrophils }+ \\ \text { Number of epithelial cells with nucleus } \\ + \text { Number of keratinocytes }\end{array}} \times 100$




\section{Evaluating on the weight of reproductive organs}

On the $15^{\text {th }}$ day, rats were sacrificed by decapitation under light anesthesia, the reproductive organs were removed (uterines, ovaries, vagina), weighed, then dried at $70^{\circ} \mathrm{C}$ to constant weight and measure weight.

Wetted weight of reproductive organs was calculated as following:

$$
\begin{aligned}
& \text { The wetted weight of reproductive organs } \\
& =\frac{\text { The weight of reproductive organs just removed }(\mathrm{mg})}{\text { The weight of the rat }(\mathrm{g})} \times 100
\end{aligned}
$$

Dried weight of reproductive organs was calculated as following:

$$
\begin{aligned}
& \text { The dried weight of reproductive organs } \\
& =\frac{\text { The weight of reproductive organs after drying }(\mathrm{mg})}{\text { The weight of the rat }(\mathrm{g})} \times 100
\end{aligned}
$$

Percentage of increased weight of reproductive organs of treated group as compared to normal group was calculated as following:

$$
\begin{aligned}
& \text { \%Increased } \\
& \text { The weight of reproductive organs of treated group - } \\
& =\frac{\text { The weight of reproductive organs of normal group }}{\text { The weight of reproductive organs of normal group }} \times 100
\end{aligned}
$$

\section{Estimating the blood estradiol concentration}

Before taking blood, mice were allowed to starve for 12 hours. On the $15^{\text {th }}$ day, before sacricing rats, take blood and then blood was centrifuged at $3000 \mathrm{rpm}$ for $10 \mathrm{~min}$ at $4^{\circ} \mathrm{C}$. The serum was used to quantify estradiol level using Estradiol ELISA kit (Eagle Biosciences) according to the manufacturer's protocols. Estradiol level was expressed as $\mathrm{pg} / \mathrm{ml}$.

\section{Statistical analysis}

All results are expressed as mean \pm SEM. Serial measurements were analyzed by using one-way ANOVA with Tukey's post hoc test using SigmaStat 3.5 program and figures were performed by using SigmaPlot 10.0 program (Systat Software Inc). The critical significance level $\alpha$ was 0.05 , and statistical significance was defined as $\mathrm{p}<0.05$.

\section{RESULTS}

The effect of PM extract on estrogenic activity on immature female rats

Estrogen is a female sex hormone that plays a role in developing and maintaining female characteristics, developing the uterus, ovary, vagina, mammary gland. Compounds with estrogenic activity may increase these weights. Therefore, we can use the weight of reproductive organs (uterines, ovaries, vaginal) to demonstrate the estrogenic activity.

\section{Effect of PM extract on the uterine's weight}

The effect of extract PM on the uterine growth of immature female rats was shown in Table 1.

\section{Wetted uterine's weight}

The rats were treated with the PM extract at dose of 100 $\mathrm{mg} / \mathrm{kg}$ and $200 \mathrm{mg} / \mathrm{kg}$ showed an increasing wet uterine's weight significantly as compared with group $1(\mathrm{p}<0.05)$.

The percentage increase was $91.8 \% ; 56.7 \%$ respectively.

\begin{tabular}{|c|c|c|c|c|}
\hline & $\begin{array}{l}\text { Wetted weight ovarian } \\
\text { (mg/100 g b.w.) }\end{array}$ & $\begin{array}{l}\% \text { increase compared } \\
\text { to group } 1\end{array}$ & $\begin{array}{l}\text { Dried weight } \\
\text { ovarian (mg/100 g b.w.) }\end{array}$ & $\begin{array}{l}\% \text { increase compared } \\
\text { to group } 1\end{array}$ \\
\hline Group 1 & $48.0 \pm 4.0$ & & $10.4 \pm 1.0$ & \\
\hline Group 2 & $73.5 \pm 2.6^{*}$ & 53.1 & $14.8 \pm 1.5$ & $42.3^{*}$ \\
\hline Group 3 & $62.7 \pm 2.9 *$ & 30.6 & $11.3 \pm 0.6$ & 8.6 \\
\hline Group 4 & $57.4 \pm 2.2 *$ & 19.6 & $12.5 \pm 1.5$ & $20.2 *$ \\
\hline
\end{tabular}
There were no differences between the doses of PM extract $(\mathrm{p}>0.05)$.

Table 1: Effect of PM extract on the uterine's weight of immature female rats.

\begin{tabular}{|lllll|}
\hline & $\begin{array}{l}\text { Wetted weight uterine } \\
(\mathbf{m g} / \mathbf{1 0 0} \mathbf{g} \mathbf{b . w})\end{array}$ & $\begin{array}{l}\text { \% increase compared } \\
\text { to group 1 }\end{array}$ & $\begin{array}{l}\text { Dried weight uterine } \\
(\mathbf{m g} / \mathbf{1 0 0} \mathbf{g} \text { b.w.) }\end{array}$ & $\begin{array}{l}\text { \% increase compared } \\
\text { to group } 1\end{array}$ \\
\hline Group 1 & $120.9 \pm 10.8$ & 146.0 & $25.2 \pm 2.6$ & 84.5 \\
\hline Group 2 & $297.4 \pm 31.2^{*}$ & 91.8 & $46.5 \pm 1.5^{*}$ & 53.2 \\
\hline Group 3 & $231.9 \pm 3.2^{*}$ & 56.7 & $38.6 \pm 3.7^{*}$ & 44.4 \\
\hline Group 4 & $189.4 \pm 16.5^{*}$ & & $36.4 \pm 1.7^{*}$ & \\
\hline
\end{tabular}

*: Significantly different from group $1(\mathrm{p}<0.05)$.

Table 2: Effect of PM extract on the ovarian's weight of immature female rats.

*: Significantly different from group $1(\mathrm{p}<0.05)$. 


\section{Dried uterine's weight}

The rats were treated with the extract of PM at doses of $100 \mathrm{mg} / \mathrm{kg}$ and $200 \mathrm{mg} / \mathrm{kg}$ also showed an increasing significantly effect on the dried uterine's weight as compared with group $1(\mathrm{p}<0.05)$. The percentage increase was $53.2 \%$; $44.4 \%$ respectively. There were no differences between doses $(100 \mathrm{mg} / \mathrm{kg}$ and $200 \mathrm{mg} / \mathrm{kg}$ ) on dried uterine's weight $(\mathrm{p}>0.05)$.

\section{Effect of PM extract on the ovarian's weight}

The effect of the extract PM on ovarian's weight of immature female rats is shown in Table 2.

\section{Wetted ovary's weight}

The rats were treated with the extract of PM at doses of $100 \mathrm{mg} / \mathrm{kg}$ and $200 \mathrm{mg} / \mathrm{kg}$ showed an increasing wetted weight ovary significantly as compared with group 1 ( $\mathrm{p}<0.05$ ). The percentage increase was $30.6 \%$ and $19.6 \%$ respectively.

\section{Dried ovary's weight}

The results showed that estradiol and the extract of PM at dose of $200 \mathrm{mg} / \mathrm{kg}$ showed an increasing significantly effect on ovarian growth as compared with group 1 $(\mathrm{p}<0.05)$.

Table 3: Effect of PM extract on the vaginal's weight of immature female rats.

\begin{tabular}{|lllll|}
\hline & $\begin{array}{l}\text { Wetted weight vaginal } \\
(\mathbf{m g} / \mathbf{1 0 0} \mathbf{g} \mathbf{b . w})\end{array}$ & $\begin{array}{l}\text { \% increase compared } \\
\text { to group 1 }\end{array}$ & $\begin{array}{l}\text { Dried weight vaginal } \\
(\mathbf{m g} / \mathbf{1 0 0} \mathbf{~ g ~ b . w . )}\end{array}$ & $\begin{array}{l}\text { \% increase compared } \\
\text { to group } 1\end{array}$ \\
\hline Group 1 & $54.9 \pm 7.0$ & 92.9 & $14.7 \pm 2.6$ & 41.5 \\
\hline Group 2 & $195.9 \pm 5.7^{*}$ & 71.4 & $20.8 \pm 1.1^{*}$ & 19.7 \\
\hline Group 3 & $94.1 \pm 7.1^{*}$ & 87.4 & $17.6 \pm 1.5^{*}$ & 36.1 \\
\hline Group 4 & $102.9 \pm 4.6^{*}$ & $20.0 \pm 2.3^{*}$ & \\
\hline
\end{tabular}

*: Significantly different from group $1(\mathrm{p}<0.05)$.

\section{Effect of PM extract on the vaginal's weight}

The effect of the PM extract on the vaginal's weight in immature female rats is shown in Table 3.

\section{Wetted vaginal's weight}

The rats were treated with the extract of PM at doses of $100 \mathrm{mg} / \mathrm{kg}$ and $200 \mathrm{mg} / \mathrm{kg}$ showed an increasing wetted vaginal's weight significantly as compared with group 1 $(p<0.05)$. The percentage increase was $71.4 \% ; 87.4 \%$ respectively. Among doses of $100 \mathrm{mg} / \mathrm{kg}, 200 \mathrm{mg} / \mathrm{kg}$, there was no difference on wetted vaginal's weight $(\mathrm{p}>0.05)$.

\section{Dried vaginal's weight}

The extract of PM at two doses showed a statistically significant effect on dried vaginal's weight as compared with group $1(\mathrm{p}<0.05)$.

\section{The effect of PM extract on estrogenic activity in mature female ovariectomized rats}

The removal of the ovaries leads to the function of the hypothalamus-pituitary-ovary is disrupted, and then the production of estrogen from the ovaries is inhibited, resulting in low levels of endogenous estrogen associated with the weight of secondary reproductive organs decreases. Therefore, female ovariectomized rats model is excluded the effect of endogenous estrogen on the change of the uterine and vagina. Then, the evaluation of the effect of enhancing estrogenic activity of exogenous samples is more accurately.
Substances with estrogenic activity stimulate the growth of vaginal epithelial cells; differentiate these cells into keratinocytes, leading to increased number of keratinocytes. Therefore, assessing the presence of keratinocytes helps to assess the estrogenic activity of the substances. The percentage of keratinocytes of mature female ovariectomized rats was shown in Figure 1. The vaginal fluid of rats treated with the PM extract at a dose of $100 \mathrm{mg} / \mathrm{kg}$ and $200 \mathrm{mg} / \mathrm{kg}$ at the fourth day contains mainly keratinocytes, the percentage of keratinocytes on the fourth day was $75.66 \%$ and $87.34 \%$, respectively.

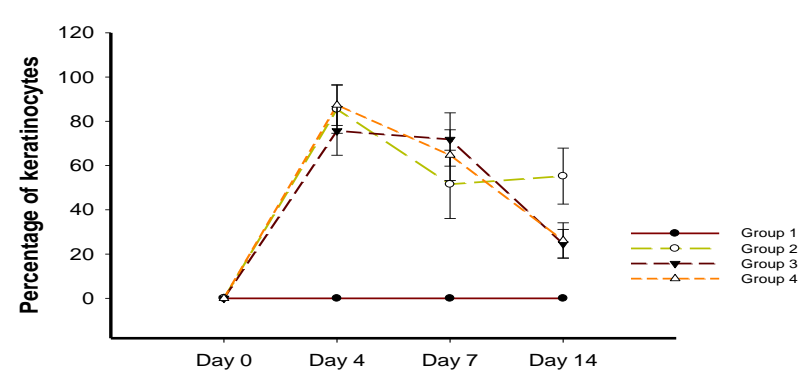

Figure 1: Effect of the PM extract on the percentage of keratinocytes of mature female ovariectomized rats.

\section{The effect of PM extract on the growth of reproductive organs}

\section{Effect on uterine's weight}

The effect of the PM extract on uterine's weight of mature ovariectomized rats was shown in Table 4 and Figure 2. 
Group 1

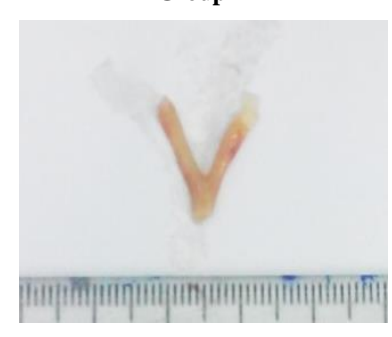

Group 3

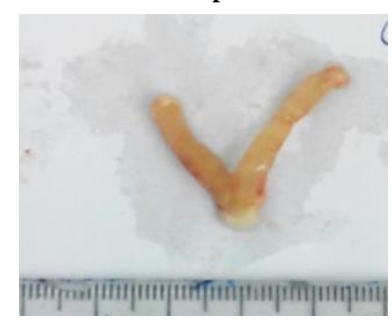

Group 2

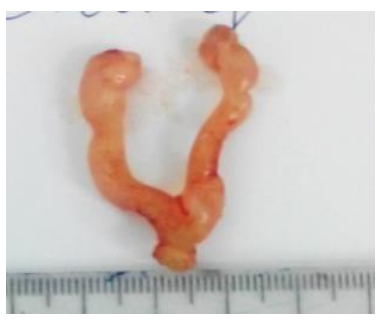

Group 4

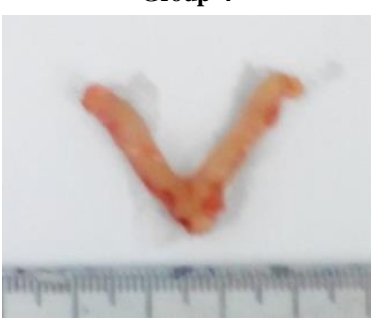

Figure 2: The effect of PM extract on uterine of mature ovariectomized rats.

Wetted uterine's weight

The rats were treated with the PM extract at both doses of $100 \mathrm{mg} / \mathrm{kg}$ and $200 \mathrm{mg} / \mathrm{kg}$ showed an increasing wetted uterine's weight, significantly as compared with group 1 $(\mathrm{p}<0.05)$. The percentage increase was $251.9 \%$ and $215.2 \%$, respectively. There were no differences between effective doses $(100 \mathrm{mg} / \mathrm{kg}, 200 \mathrm{mg} / \mathrm{kg})$ on wetted uterine's weight of the studied animals ( $p>0.05)$.

\section{Dried uterine's weight}

The rats were treated with the PM extract at both doses of $100 \mathrm{mg} / \mathrm{kg}, 200 \mathrm{mg} / \mathrm{kg}$ showed significantly increasing dried uterine's weight as compared with group 1 $(\mathrm{p}<0.05)$. The percentage increase was $281.9 \%$ and $261.1 \%$, respectively. There were no differences between effective doses (100 mg/kg, $200 \mathrm{mg} / \mathrm{kg})$ on dried uterine's weight of the studied animals $(\mathrm{p}>0.05)$.

\section{Effect on vaginal's weight}

The effect of the PM extract on vaginal's weight of mature ovariectomized rats is shown in Table 5.

Wetted vaginal's weight

The rats were treated with the PM extract at doses of 100 $\mathrm{mg} / \mathrm{kg}$ and $200 \mathrm{mg} / \mathrm{kg}$ have a statistically significant increase wetted vaginal's weight as compared to the group $1(\mathrm{p}<0.01)$. The percentage increase was $62.3 \%$ and $78.7 \%$, respectively.

\section{Table 5: Effect of PM extract on the vaginal's weight of mature female ovariectomized rats.}

\begin{tabular}{|c|c|c|c|c|}
\hline & $\begin{array}{l}\text { Wetted weight vaginal } \\
\text { (mg/100 g b.w.) }\end{array}$ & $\begin{array}{l}\% \text { increase compared } \\
\text { to group } 1\end{array}$ & $\begin{array}{l}\text { Dried weight vaginal } \\
\text { (mg/100 } \mathrm{g} \mathrm{b.w.)}\end{array}$ & $\begin{array}{l}\% \text { increase compared } \\
\text { to group } 1\end{array}$ \\
\hline Group 1 & $61.0 \pm 6.0$ & & $11.9 \pm 1.3$ & \\
\hline Group 2 & $107.0 \pm 12.0 *$ & 75.4 & $22.3 \pm 2.4^{*}$ & 87.4 \\
\hline Group 3 & $99.0 \pm 8.0^{*}$ & 62.3 & $29.3 \pm 7.2 *$ & 146.2 \\
\hline Group 4 & $109.0 \pm 7.0^{*}$ & 78.7 & $20.2 \pm 1.9^{*}$ & 69.8 \\
\hline
\end{tabular}

*: Significantly different from group $1(\mathrm{p}<0.05)$.

Table 6: Effect of PM extract on the serum estradiol concentration of mature female ovariectomized rats.

\begin{tabular}{|lll|}
\hline & Estradiol $(\mathrm{pg} / \mathrm{ml})$ & \% increase compared to group 1 \\
\hline Group 1 & $27.54 \pm 11.19$ & 320.43 \\
\hline Group 2 & $8852.33 \pm 199.44^{*}$ & 207.08 \\
\hline Group 3 & $84.57 \pm 17.73^{*}$ & 235.54 \\
\hline Group 4 & $92.41 \pm 31.87^{*}$ & \\
\hline
\end{tabular}

*: Significantly different from group $1(\mathrm{p}<0.05)$.

\section{Dried vaginal's weight}

The rats were treated with the PM extract at doses of 100 $\mathrm{mg} / \mathrm{kg}$ and $200 \mathrm{mg} / \mathrm{kg}$ showed strong effect on increasing dried vaginal's weight as compared to group $1(\mathrm{p}<0.01)$. The percentage increase was $146.2 \%$ and $69.8 \%$, respectively.

\section{The effect of PM extract on serum estradiol concentration}

The PM extract at both doses of $100 \mathrm{mg} / \mathrm{kg}$ and 200 $\mathrm{mg} / \mathrm{kg}$ increased the concentration of estradiol as compared to group $1 \quad(\mathrm{p}<0.05)$ with the percentage increase was $207.08 \%$ and $235.54 \%$ respectively (Table 6).

\section{DISCUSSION}

Estrogen is a hormone that stimulates cell division and growth of some tissues in female mammals such as the uterus, cervix and vagina. ${ }^{10}$ Therefore, in order to evaluate the effect of PM on initial estrogenic activity, we evaluated on immature rats through the growth of reproductive organs including uterines, ovaries, vagina 
and mature female ovariectomized rats. ${ }^{11}$ Our data showed that PM extract increased wetted and dried uterine weight of immature rats at doses of 100 and 200 $\mathrm{mg} / \mathrm{kg}$ b.w. This increase may be due to PM increases fluid retention and electrolytes and stimulates the growth of uterine tissue. We also showed that PM extract increased wetted and dried vaginal's weight in immature rats. This shows that PM extract also enhances the development of vaginal muscle tissue, which is the characteristic of estrogenic activity.

The removing ovary cause to loss the function of the hypothalamus-pituitary-ovary, inhibit to produce estrogen from the ovaries, lead to the reduction of endogenous estrogen concentration circulating in the blood and the weight of reproductive organs. ${ }^{12}$ Therefore, changes in weight of the uterine and vagina due to the effect of endogenous estrogens are excluded in the mature female ovariectomized rat's model. Using mature female ovariectomized rats is accurately method to evaluate the estrogenic activity of exogenous substances. ${ }^{13}$ The changes on the reproductive organs are mainly influenced by experimental substances. In this study, we evaluated the estrogenic effect of PM extract on mature female ovariectomized rats at two doses of 100 and $200 \mathrm{mg} / \mathrm{kg}$ b.w. on vaginal epithelial cell growth, the weight of reproductive organs including uterines, vagina and serum estradiol concentration. Our data showed that PM extract could induce the appearance of keratinocytes about 2-3 days after treatment. By day fourth, mainly keratinocytes presented in vaginal fluids. This results confirmed that PM extract had estrogenic activity through the effect of the vaginal epithelial cells converted into keratinocytes. $^{6,14}$ We also showed that PM extract at doses of $100 \mathrm{mg} / \mathrm{kg}$ and $200 \mathrm{mg} / \mathrm{kg}$ increased both wetted and dried weight of reproductive organs including uterines and vagina significantly as compared with control group. Our results are agreed with previous studied such as Malaivijitnond and colleagues. ${ }^{14}$ These authors have assessed the estrogenic activities of three distinct cultivars of PM. Their data have shown that PM could increase the uterine weight and cornification of vaginal epithelium in manner dose-dependent. Similar, Cherdshewasart and colleagues also showed the estrogenic activity of PM depends on seasonal changes and plant cultivars. ${ }^{15}$ They also showed the PM at 1 $\mu \mathrm{g} / \mathrm{ml}$ exhibited significant breast cancer cell line MCF- 7 proliferation similar to 17 beta-estradiol. ${ }^{16}$ Furthermore, we showed that PM at dose of 100 and $200 \mathrm{mg} / \mathrm{kg}$ increased serum estradiol concentration in mature female ovariectomized rats as compared to the control group $(\mathrm{p}<0.05)$.

\section{CONCLUSION}

In this study we demonstrated that the PM extract had estrogenic activity in immature female rats by increasing reproductive organs weight such as uterine, ovarian and vaginal. Furthermore, the PM extract also increased the reproductive organs weight in mature female ovariectomized rats, increasing vaginal epithelial cells growth and increasing serum estradiol levels. Our study showed that PM could be useful as an alternative for hormone replacement therapy.

\section{Funding: No funding sources}

Conflict of interest: None declared

Ethical approval: The study was approved by the Institutional Ethics Committee

\section{REFERENCES}

1. Malaivijitnond S. Medical applications of phytoestrogens from the Thai herb Pueraria mirifica. Frontiers Med. 2012;6(1):8-21.

2. Yusakul G, Putalun W, Udomsin O, Juengwatanatrakul T, Chaichantipyuth C. Comparative analysis of the chemical constituents of two varieties of Pueraria candollei. Fitoterapia. 2011;82(2):203-7.

3. Cherdshewasart W, Sutjit W, Pulcharoen K, Panriansaen R, Chulasiri M. Antimutagenic potential of the Thai herb, Mucuna collettii Lace. J Ethnopharmacol. 2008;115(1):96-103.

4. Suthon S, Jaroenporn $\mathrm{S}$, Charoenphandhu $\mathrm{N}$, Suntornsaratoon P, Malaivijitnond S. Antiosteoporotic effects of Pueraria candollei var. mirifica on bone mineral density and histomorphometry in estrogen-deficient rats. J Nat Med. 2016;70(2):225-33.

5. Chattuwatthana T, Okello E. Anti-collagenase, antielastase and antioxidant activities of Pueraria candollei var. mirifica root extract and coccinia grandis fruit juice extract: an in vitro study. Europ $\mathbf{J}$ Med Plant. 2015;5(4):318.

6. Cherdshewasart W, Kitsamai Y, Malaivijitnond S. Evaluation of the estrogenic activity of the wild Pueraria mirifica by vaginal cornification assay. J Reprod Develop. 2007;53(2):385-93.

7. Sookvanichsilp N, Soonthornchareonnon N, Boonleang C. Estrogenic activity of the dichloromethane extract from Pueraria mirifica. Fitoterapia, 2008;79(7-8):509-14.

8. No OT. Uterotrophic bioassay in rodents: a shortterm screening test for oestrogenic properties. OECD guidelines for the testing of chemicals. 2007: 4.

9. Parhizkarsup S, Latiff LA, Rahman SA, Dollah MA, Parichehr H. Assessing estrogenic activity of Nigella sativa in ovariectomized rats using vaginal cornification assay. Afr $\mathrm{J}$ Pharm Pharmacol. 2011;5(2):137-42.

10. Manolagas SC, O'brien CA, Almeida M. The role of estrogen and androgen receptors in bone health and disease. Nature Reviews Endocrinol. 2013;9(12):699.

11. Uterotrophic Assay. Standard evaluation procedure (SEP). Endocrine Disruptor Screening Program. OCSPP Guideline 890.1600. Washington, DC: 2011; 20460.

12. De Vos M, Devroey P, Fauser BC. Primary ovarian insufficiency. Lancet. 2010;376(9744):911-21. 
13. Ke HZ, Chen HK, Simmons HA, Qi H, Crawford DT, Pirie CM. Comparative effects of droloxifene, tamoxifen, and estrogen on bone, serum cholesterol, and uterine histology in the ovariectomized rat model. Bone. 1997;20(1):31-9.

14. Malaivijitnond S, Chansri K, Kijkuokul P, Urasopon $\mathrm{N}$, Cherdshewasart W. Using vaginal cytology to assess the estrogenic activity of phytoestrogen-rich herb. J Ethnopharmacol. 2006;107(3):354-60.

15. Cherdshewasart W, Sriwatcharakul S, Malaivijitnond S. Variance of estrogenic activity of the phytoestrogen-rich plant. Maturitas. 2008;61(4):3507.

16. Cherdshewasart W, Traisup V, Picha P. Determination of the estrogenic activity of wild phytoestrogen-rich Pueraria mirifica by MCF-7 proliferation assay. J Reprod Dev. 2008;54(1):63-7.

Cite this article as: Vui DT, Hang NT, Huy NQ, Tung BT. Investigation of the estrogenic activity of Pueraria candollei variety mirifica extract on rats. Int J Basic Clin Pharmacol 2019;8:2172-8. 